\title{
KARAKTERISASI SECARA MORFOLOGI PATOGEN BULAI PADA TANAMAN JAGUNG DI KABUPATEN LAMPUNG TIMUR
}

\section{EFFICACY OF METSULFURON-METHYL HERBICIDE IN CONTROLLING WEEDS IN RUBBER PLANTATION (Hevea brasiliensis) IMMATURE PLANT}

\author{
Ichwan Surya Nugraha' ${ }^{1)}$, Joko Prasetyo ${ }^{2)}$, Ivayani' ${ }^{2}$, \& Hasriadi Mat Akin ${ }^{2)}$ \\ ${ }^{1}$ Jurusan Agroteknologi, Fakultas Pertanian, Universitas Lampung, Bandar Lampung, Indonesia \\ ${ }^{2}$ Jurusan Proteksi Tanaman, Fakultas Pertanian, Universitas Lampung, Bandar Lampung, Indonesia \\ *Email: ichwansurya@gmail.com \\ *Corresponding Author, Diterima: 6 Apr. 2021, Direvisi: 29 Apr. 2021, Disetujui: 6 Mei 2021
}

\begin{abstract}
The cause of maize downy mildew in the Province of Lampung is Pernosclerospora sp. Recently a report mentions that the downy mildew on maize in Indonesia were caused by several species of Peronosclerospora. This study aimed to determine the pathogen that causes downy mildew and its characteristics on maize in East Lampung Regency. The research was done from January 2018 to March 2018 in Hajimena District Natar, South Lampung and the Laboratory of Plant Pests and Diseases, Faculty of Agriculture, University of Lampung. The research was conducted by looking for the maize which had downy mildew symptoms in East Lampung regency. The diseased plant was observed and indentified its pathogen. The results showed that the species of Peronosclerospora sp found on maize in East Lampung Regency was P. sorghi. The characteristic of the fungi are at 12.00 a.m. began to form early structure of conidiophores, then at 01.00 a.m. conidiophores began to form branches, at 02.00 a.m. conidiophores have been formed a perfect branching level and conidia develop, at 03.00 a.m. P. sorghi has formed a perfect structure, at 04.00 a.m. the conidia has mature, and at 05.00 a.m. the conidia began to detach from the conidiophores, other characteristic was oospore formation.
\end{abstract}

Keywords: Characterization of Perosclerospora sp., Downy mildew, P. sorghi

\begin{abstract}
ABSTRAK
Penyebab penyakit bulai di Provinsi Lampung disebabkan oleh Pernosclerospora sp. Beberapa tahun terakhir ini laporan menyebutkan bahwa penyakit bulai pada tanaman jagung yang ada di Indonesia disebabkan oleh beberapa spesies Peronosclerospora. Penelitian ini bertujuan mengetahui spesies patogen bulai dan karakterisasinya pada tanaman jagung di Kabupaten Lampung Timur. Penelitian dilaksanakan pada bulan Januari 2018 sampai dengan Maret 2018 di lahan pertanian Hajimena Kecamatan Natar, Lampung Selatan dan di Laboratorium Ilmu Hama dan Penyakit Tanaman, Fakultas Pertanian, Universitas Lampung. Penelitian dilaksanakan dengan melakukan survei tanaman jagung yang bergejala penyakit bulai pada kabupaten Lampung Timur, kemudian dilakukan pengamatan pada tanaman jagung yang bergejala bulai, di identifikasi penyebab penyakit bulai, morfologi Peronosclerospora sp., dan oospora. Hasil penelitian menunjukkan bahwa spesies Peronosclerospora sp yang ditemukan pada tanaman jagung di Kabupaten Lampung Timur adalah P. sorghi. Konidiofor $P$. sorghi mulai terbentuk pada pukul 00.00, kemudian pada pukul 01.00 konidiofor sudah mulai membentuk percabangan, pada pukul 02.00 konidiofor sudah membentuk tingkat percabangan sempurna dan
\end{abstract}


mulai terlihat bakal konidia, pada pukul 03.00 P. sorghi sudah membentuk struktur yang sempurna, pukul 04.00 konidia sudah mulai masak, dan pada pukul 05.00 konidia mulai terlepas dari konidiofor, karakteristik lain dari P. sorghi adalah terdapat pembentukan oospora.

Kata kunci : Karakterisasi Perosclerospora sp., bulai, P. sorghi

\section{PENDAHULUAN}

Jagung (Zea mays) merupakan salah satu sumber bahan pakan di Indonesia yang termasuk dalam salah satu dari lima komoditas program utama pemerintah dengan menitikberatkan pada swasembada yang berkelanjutan. Hal ini dilakukan karena permintaan jagung secara nasional terus meningkat sejalan dengan berkembangnya usaha industri pakan ternak dan makanan olahan (Mauke et al., 2015).

Provinsi Lampung merupakan salah satu penyumbang produksi jagung terbesar di Indonesia, yakni berada di urutan ke 3. Menurut Badan Pusat Statistik Provinsi Lampung (2016) terdapat beberapa Kabupaten di Provinsi Lampung yang memiliki potensi produksi jagung cukup tinggi. Produksi jagung di Provinsi Lampung pada tahun 2010 mencapai 2.126.751 ton, sedangkan pada tahun 2011 dan 2012 mengalami penurunan menjadi 1.817.906 ton dan 1.760.275 ton, kemudian pada tahun 2013 produksi jagung di Lampung mengalami peningkatan menjadi 1.760.278 ton. Pada tahun 2014 dan 2015 produksi jagung kembali mengalami penurunan menjadi 1.719.386 ton dan 1.502.800 ton. Penyebab penurunan produksi tanaman jagung salah satunya adalah penyakit bulai (downy mildew) yang disebabkan oleh jamur Peronosclerospora sp. dan dapat menyebabkan kehilangan hasil mencapai 90\% (Matruti et al., 2013). Gejala penyakit bulai ini dapat dilihat dengan adanya warna klorosis memanjang sejajar tulang daun dengan batas terlihat jelas antara daun sehat dan sakit. Saat pagi hari pada bagian atas dan bawah permukaan daun terdapat warna putih seperti tepung (Sugiono, 2016).

Di Indonesia penyebab penyakit bulai ini terdapat tiga spesies yaitu Peronosclerospora maydis, P. philippinensis, dan P. sorghi. P. maydis ditemukan menyerang tanaman jagung di pulau Kalimantan dan Jawa, $P$. sorghi ditemukan di pulau Sumatera, dan $P$. philippinensis ditemukan di Minahasa, Sulawesi Utara (Hikmawati et al., 2011). Di Provinsi Lampung penyebab penyakit bulai disebabkan oleh Peronosclerospora sp. keragaman dari penyebaran penyakit bulai di Provinsi Lampung dipengaruhi oleh kondisi lingkungan yang relatif berbeda seperti suhu, kelembaban, dan faktor lainnya dapat mempengaruhi pertumbuhan dan perkembangan patogen tersebut. Hal tersebut dapat mempengaruhi perkembangan dari jamur penyebab bulai, sehingga perkembangan konidiofor dan konidia dari patogen tersebut berbeda-beda.

Untuk mengetahui perkembangan dari jamur penyebab penyakit bulai di Kabupaten Lampung Timur, maka perlu dilakukan penelitian mengenai identifikasi dan perkembagan konidia dan konidiofor Peronosclerospora sp. yang ada di Kabupaten Lampung Timur. Penelitian ini bertujuan untuk mengetahui penyebab penyakit bulai di Kabupaten 
Lampung Timur dan karakter perkembangan morfologi Peronosclerospora sp pada tanaman jagung di Lampung Timur.

\section{BAHAN DAN METODE}

Penelitian ini dilaksanakan di Laboratorium Ilmu Hama dan Penyakit Tanaman, Fakultas Pertanian, Universitas Lampung dari bulan Januari 2018 sampai dengan Maret 2018. Sampel tanaman sakit diambil dari Kabupaten Lampung Timur

Penelitian ini dilaksanakan dengan melakukan observasi tanaman jagung yang bergejala penyakit bulai. Sampel tanaman diambil dari Kabupaten Lampung Timur, dengan dipilih 2 lahan dari lokasi yang berbeda, kemudian dari setiap lokasi diambil 2 sampel tanaman.

Penanaman tanaman yang akan Diamati, dilakukan pada rumah plastik di Hajimena Kecamatan Natar, Lampung selatan. Benih yang digunakan adalah varietas $\mathrm{P} 27$ yang ditanam pada rumah plastik sebanyak 20 tanaman. Benih jagung ditanam pada polibag yang telah berisi tanah dan pupuk kandang dengan perbandingan 2:1, masing-masing dua benih per polibag.

Pengambilan Sampel, tanaman sampel yang diambil yaitu tanaman pada fase pertumbuhan vegetatif dan menunjukan gejala penyakit bulai, ditandai dengan gejala klorosis pada bagian daun dan tulang daun. Sampel tanaman yang diambil kemudian dipindahkan ke dalam polibag yang telah berisi tanah dan pupuk kandang dengan perbandingan 2:1 dan diletakkan di dalam rumah plastik dengan tujuan agar Peronosclerospora sp. tidak tercampur dari lokasi lain. Tanaman ini dijadikan sebagai sumber inokulum untuk tanaman yang lain.
Inokulasi Tanaman yang akan Diamati, inokulasi Peronosclerospora sp. dilakukan pada saat tanaman berumur 7 hari setelah tanam(HST). Inokulasi dilakukan pada pukul 04.30 WIB, dengan melakukan pengambilan konidia terlebih dahulu dari tanaman sampel yang terserang Peronosclerospora sp. Pengambilan konidia dilakukan dengan menggunakan kuas dan dialirkan air pada daun yang bergejala, kemudian ditampung dalam piring plastik yang berisi air steril $20 \mathrm{ml}$. Suspensi konidia Peronosclerospora sp. kemudian diteteskan pada titik tumbuh tanaman uji dengan menggunakan pipet tetes sebanyak 2-3 tetes per tanaman. Tanaman dibiarkan hingga menunjukan gejala penyakit bulai, kemudian akan diamati pada saat tanaman berumur 14 HST, 21 HST, dan 28 HST.

Penyiapan Tanaman yang akan Diamati, Tanaman yang sudah menunjukan gejala terserang Peronosclerospora sp. diambil, kemudian dibawa ke Laboratorium Ilmu Hama dan Penyakit. Pada sore hari, daun ketiga yang menunjukkan gejala bulai dicuci dengan air mengalir, dengan cara mengusap daun menggunakan dua jari dan disiram selanjutnya dilap dan dikeringkan menggunakan tisu setelah itu disiram kembali. Tanaman yang telah dibersihkan daunnya kemudian dimasukkan ke dalam ruang bersuhu $18^{\circ} \mathrm{C}$ dan disungkup dengan plastik selama 6 jam. Penyiraman dan pencucian daun ini bertujuan untuk memastikan stomata daun bersih dari kotoran dan propagul jamur. Peletakan tanaman di ruang bersuhu $18^{\circ} \mathrm{C}$ dan penyungkupan bertujuan agar tanaman berada dalam kondisi lembab dan dingin sehingga jamur dapat tumbuh dengan baik. 
Identifikasi Penyebab Penyakit Bulai, identifikasi Peronosclerospora sp. penyebab bulai dilakukan berdasarkan karakteristik morfologi meliputi panjang konidiofor, diameter konidia, bentuk konidia, dan diameter oospora yang dikemukakan oleh CIMMYT (2012), yang dapat dilihat pada (Tabel 1).

\section{Karakterisasi secara morfologi}

Peronosclerospora sp, dilakukan dengan mengamati diameter konidia, panjang konidiofor, tingkat percabangan, dan diameter oospora Peronosclerospora sp. Pengamatan dilakukan dengan menggunakan mikroskop majemuk binokuler (Leica ICC50 HD). Pengambilan konidia yang akan diamati dilakukan dengan mengarahkan sorot lampu senter ke daun berlawananan arah dengan pandangan pengamat, kemudian diambil konidia jamur yang berwarna putih dengan menggunakan cover glass kemudian oospora yang terkumpul diletakkan pada kaca objek yang sudah ditetesi aqudestilata lalu ditutup dengan cover glass, kemudian diamati di bawah mikroskop majemuk dengan perbesaran 400x. Pengambilan sampel yang diamati dilakukan setiap satu jam sekali dimulai dari pukul 00.00 WIB 605.00 WIB. Tanaman jagung yang bergejala lanjut berupa daun yang sudah mengering khas bulai yang ditandai dengan warna yang lebih coklat diambil untuk diamati oospora yang terdapat pada tanaman tersebut. Pengamatan dilakukan dengan mengerok daun menggunakan cover glass yang telah ditetesi aquadestilata kemudian oospora yang terkumpul diletakkan pada kaca objek yang sudah ditetesi aquadestilata sebelumnya setelah itu, diamati dibawah mikroskop majemuk dengan perbesaran 400x.

\section{HASIL DAN PEMBAHASAN}

\section{Identifikasi Penyebab Penyakit Bulai, Hasil}

identifikaasi Peronosclerospora sp. isolat Lampung Timur menunjukan bahwa Peronosclerospora sp. memiliki tingkat percabangan 1-3, rata-rata panjang konidiofor 155-338,60 ìm, rata-rata diameter konidia 14,24-21,40×15,40-22,40 ìm, bentuk konidia oval (Tabel 2), ditemukan oospora berwarna kuning terang hingga kecoklatan berbentuk bulat (Gambar 1d) dengan diameter 21,46 ìm. Dari hasil identifikasi tersebut maka dapat diketahui bahwa penyebab penyakit bulai pada tanaman jagung di Kabupaten Lampung Timur berdasarkan deskripsi CIMMYT (2012) adalah P. sorghi (Tabel 2). P. sorghi menurut CIMMYT (2012) memiliki panjang konidiofor 180-300 ìm, konidia berbentuk oval dengan diameter 14,4-27,3×15-28,9 ìm, tingkat percabangan 2 , dan oospora berbentuk bulat dengan warna kuning hingga kecoklatan (Tabel 1). Morfologi P. sorghi yang ditemukan pada penelitian ini memiliki

Tabel 2. Hasil identifikasi morfologi Peronosclerospora sp. berdasarkan (CIMMYT, 2012).

\begin{tabular}{|c|c|c|c|}
\hline No & Isolat & Morfologi & Identitas \\
\hline 1 & Lampung Timur & $\begin{array}{l}\text { Bentuk konidia oval, tingkat percabangan 1-3, panjang } \\
\text { konidiofor } 155-338,60 \mu \mathrm{m} \text {, diameter konidia } 14,24- \\
21,40 \times 15,40-22,40 \mu \mathrm{m} \text {, dan ditemukan oospora } \\
\text { berwarna kuning terang hingga kecoklatan dengan } \\
\text { bentuk bulat dengan diameter } 21,46 \mu \mathrm{m} \text {. }\end{array}$ & $\begin{array}{l}\text { Peronosclerospora } \\
\text { sorghi }\end{array}$ \\
\hline
\end{tabular}


Tabel 1. Identifikasi Peronosclerospora sp. penyebab bulai berdasarkan karakteristik morfologi yang dikemukakan oleh CIMMYT (2012).

\begin{tabular}{|c|c|c|c|}
\hline \multirow{2}{*}{ Patogen } & \multicolumn{3}{|c|}{ Karakteristik Morfologi } \\
\hline & Konidiofor/ Sporangiofor & Konidia/Sporangia & Oospora \\
\hline $\begin{array}{l}\text { Peronosclerospora } \\
\text { sorghi }\end{array}$ & $\begin{array}{l}\text { Tegak, bercabang } 2 \text {, panjang } \\
\text { konidiofor } 180-300 \mu \mathrm{m} \text {. tumbuh } \\
\text { berkelompok pada stomata. }\end{array}$ & $\begin{array}{l}\text { Oval }(14.4-27.3 \times 15- \\
28.9 \mu \mathrm{m})\end{array}$ & $\begin{array}{l}\text { Bulat (diameter rata-rata } \\
36 \mu \mathrm{m} \text { ), berwarna kuning } \\
\text { terang hingga kecoklatan. }\end{array}$ \\
\hline P. maydis & $\begin{array}{l}\text { Bercabang dua sampai empat, } \\
\text { panjang panjang } 150-550 \mu \mathrm{m}, \\
\text { konidiofor tumbuh berkelompok } \\
\text { pada stomata. }\end{array}$ & $\begin{array}{l}\text { Bulat hinnga } \\
\text { subsperikal }(17-23 \\
\mu \mathrm{m} \times 27-39 \mu \mathrm{m}) .\end{array}$ & Tidak Dilaporkan \\
\hline P. philippinensis & $\begin{array}{l}\text { Konidiofor tegak, bercabang dua } \\
\text { hingga empat, dengan panjang } \\
150-400 \mu \mathrm{m} \text { dan muncul dari } \\
\text { stomata }\end{array}$ & $\begin{array}{l}\text { Seperti telur hingga } \\
\text { silinder }(17-21 \mu \mathrm{m} x \\
27-38 \mu \mathrm{m}) \text {, sedikit } \\
\text { membulat pada bagian } \\
\text { atas. }\end{array}$ & $\begin{array}{l}\text { Jarang ditemukan, bulat } \\
\text { (berdiameter } 25-27 \mu \mathrm{m} \\
\text { dan memiliki dinding). }\end{array}$ \\
\hline P. sacchari & $\begin{array}{l}\text { Memiliki panjang } 160-170 \mu \mathrm{m} \\
\text { dan muncul dari stomata secara } \\
\text { tunggal atau berpasangan. }\end{array}$ & $\begin{array}{l}\text { Elips, lonjong }(15-23 \\
\mu \mathrm{m} \times 25-41 \mu \mathrm{m}) \\
\text { dengan ujung yang } \\
\text { bulat. }\end{array}$ & $\begin{array}{l}\text { Bulat, berdiameter } 40-50 \\
\mu \mathrm{m} \text { dan berwarna kuning. }\end{array}$ \\
\hline $\begin{array}{l}\text { Sclerospora } \\
\text { graminicola }\end{array}$ & Panjang rata-rata $268 \mu \mathrm{m}$. & $\begin{array}{l}\text { Bulat panjang }(12-21 \\
\mathrm{x} 14-31 \mu \mathrm{m}) \text { dengan } \\
\text { bagian atas berbentuk } \\
\text { runcing. }\end{array}$ & $\begin{array}{l}\text { Berdiameter } 22-35 \mu \mathrm{m} \\
\text { dan berwarna coklat } \\
\text { pucat }\end{array}$ \\
\hline $\begin{array}{l}\text { Sclerophthora } \\
\text { macrospora }\end{array}$ & Sangat pendek (rata-rata $14 \mu \mathrm{m}$ ). & $\begin{array}{l}\text { Seperti lemon }(30-65 \\
\text { x } 60-100 \mu \mathrm{m})\end{array}$ & $\begin{array}{l}\text { Bundar }(45-75 \mu \mathrm{m}) \text { dan } \\
\text { berwana kuning pucat, }\end{array}$ \\
\hline $\begin{array}{l}\text { Scleropthora } \\
\text { rayssiae var. zeae }\end{array}$ & & $\begin{array}{l}\text { Oval hingga silinder } \\
(18-26 \times 29-67 \mu \mathrm{m}) \text {. }\end{array}$ & $\begin{array}{l}\text { Bulat (berdiameter } 29-37 \\
\mu \mathrm{m} \text { ) dan berwarna coklat }\end{array}$ \\
\hline
\end{tabular}
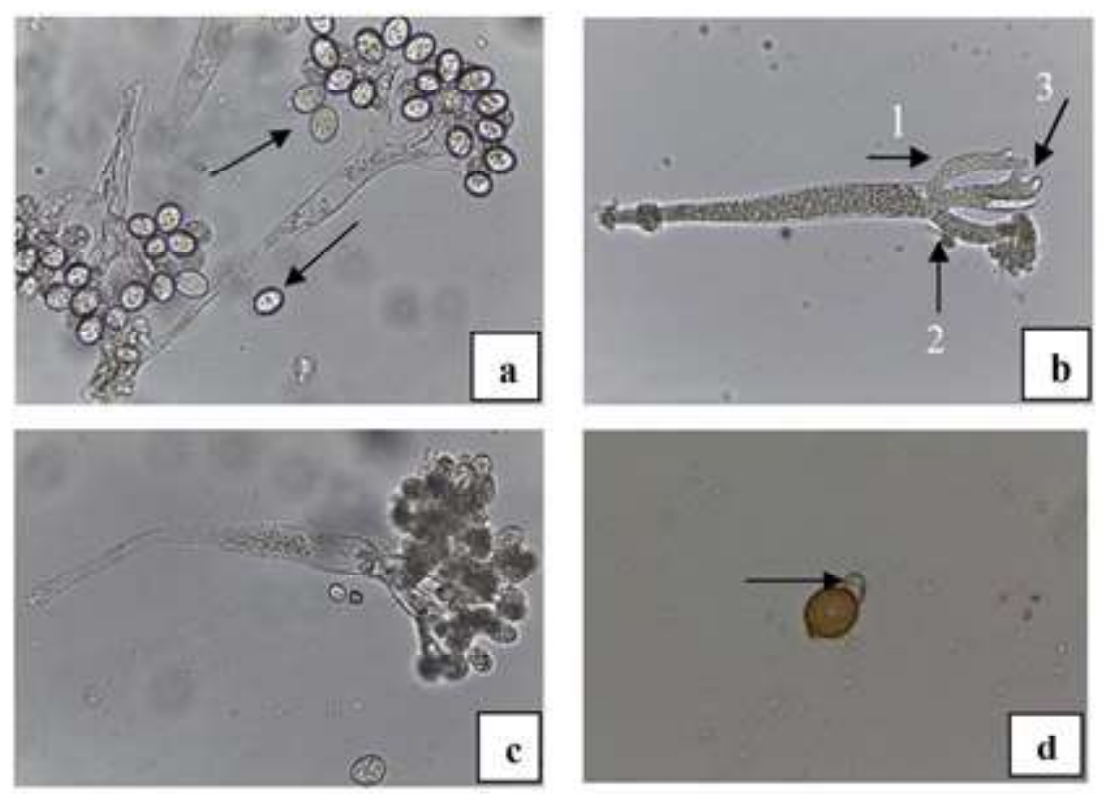

Gambar 1. P. sorghi, konidia P. sorghi berbentuk oval (a), konidiofor dengan tingkat percabangan 1-3 (b), morfologi konidiofor utuh (c), oospora dari P. sorghi yang diamati di bawah mikroskop majemuk kamera dengan perbesaran $400 \times(d)$. 
ukuran konidia yang mendekati dengan deskripsi CIMMYT (2012) namun memiliki konidiofor yang lebih panjang dibandingkan dengan yang dikemukakan oleh CIMMYT (2012) dan Rustiani et al. (2015).

Konidia yang ditemukan memiliki bentuk yang sama yaitu oval-bulat (Gambar 1a), selain itu P. sorghi pada isolat yang diamati juga ditemukan oospora berwarna coklat kekuningan (Gambar 3) dengan diameter 21,46 ìm (Tabel 2). Bentuk oospora yang diamati dibawah mikroskop majemuk kamera dengan perbesaran $100 " 400 \times$ yaitu bulat sesuai dengan deskripi oleh CIMMYT (2012).

Perkembangan Morfologi P. sorghi, Pengamatan konidia, konidiofor, dan tingkat percabangan menunjukkan bahwa pada pukul 00.00 konidiofor mulai terbentuk. Bentuk konidiofor pada fase pertama ini masih berbentuk seperti tombak yang tumpul (Gambar 2a). Fase kedua terjadi antara pukul 01.00-02.00, pada fase kedua ini konidiofor sudah mulai terlihat membentuk percabangan, dengan tingkat percabangan 1-2 (Gambar 2b). Fase ketiga terjadi antara pukul 02.00-03.00, konidiofor sudah terlihat menunjukkan tingkat percabangan 1-3 dan konidia sudah mulai akan terbentuk (Gambar 2c). Fase keempat terjadi antara pukul 03.00-04.00, pada fase ini P. sorghi sudah membentuk struktur yang sempurna, konidia yang terlihat yaitu berbentuk oval (Gambar 2d). Fase kelima terjadi antara pukul 04.00-05.00, pada fase ini konidia sudah masak, dan terdapat beberapa konidia yang mulai terlepas dari konidiofor (Gambar 2e). Fase keenam terjadi antara pukul 05.00-06.00, pada fase ini terlihat konidia sudah terlepas dari konidiofor (Gambar 2f).
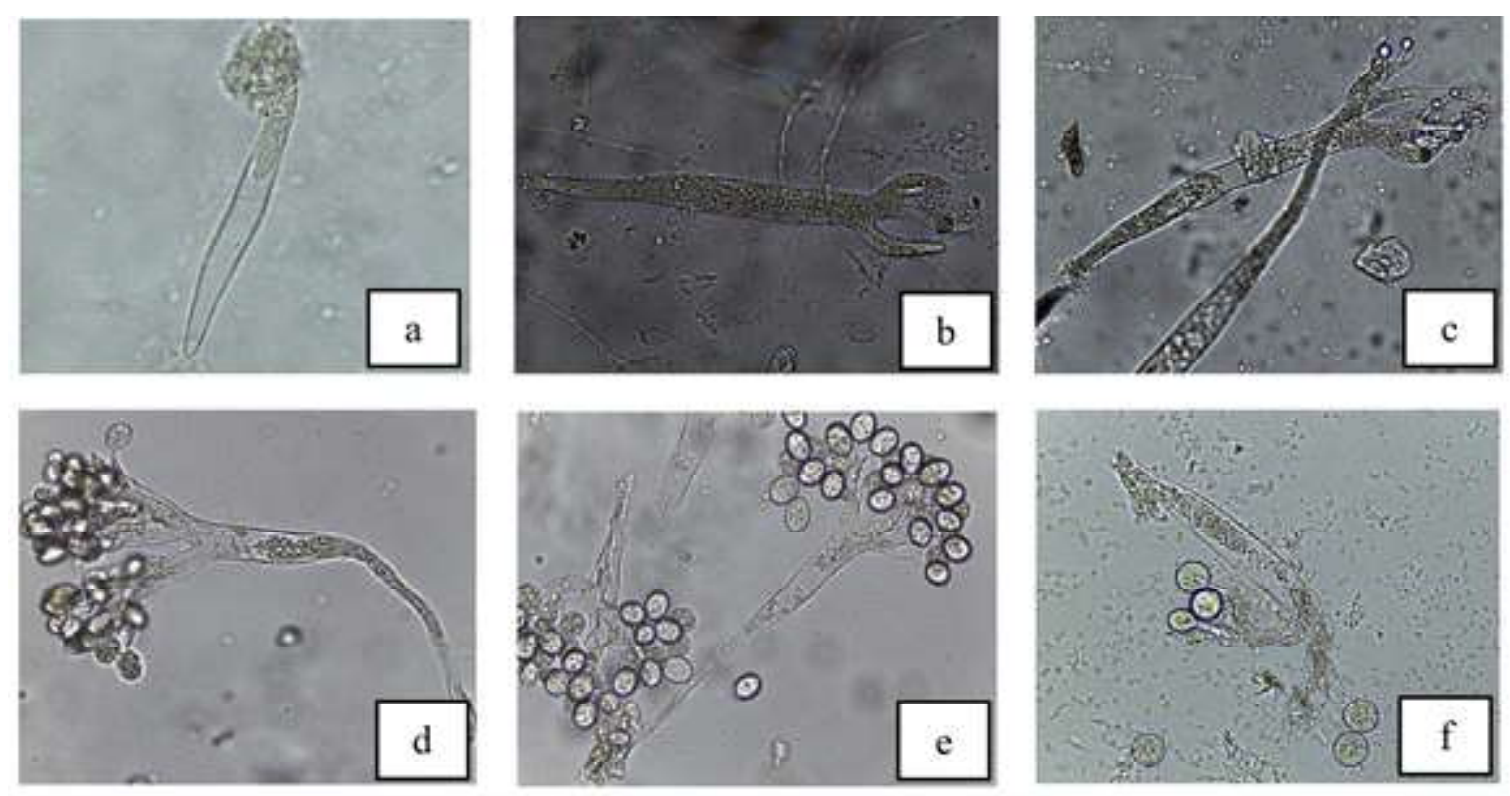

Gambar 2. Perkembangan morfologi P. sorghi dari pukul 00.00-05.00 WIB yang diamati di bawah mikroskop majemuk kamera dengan perbesaran $400 \times$, konidiofor $P$. sorghi mulai terbentuk pada pukul 00.00(a), konidiofor sudah mulai bercabang pada pukul $01.00 \mathrm{WIB}$ (b), konidia P. sorghi mulai muncul pada pukul $02.00 \mathrm{WIB}$ (c), konidia sudah mulai berkembang secara optimum pada pukul 03.00 WIB (d), konidia mulai terlepas dari Konidiofor pada pukul 04.00 WIB (e), konidia sudah terlepas seluruhnya dari konidiofor pada pukul 05.00 WIB (f). 


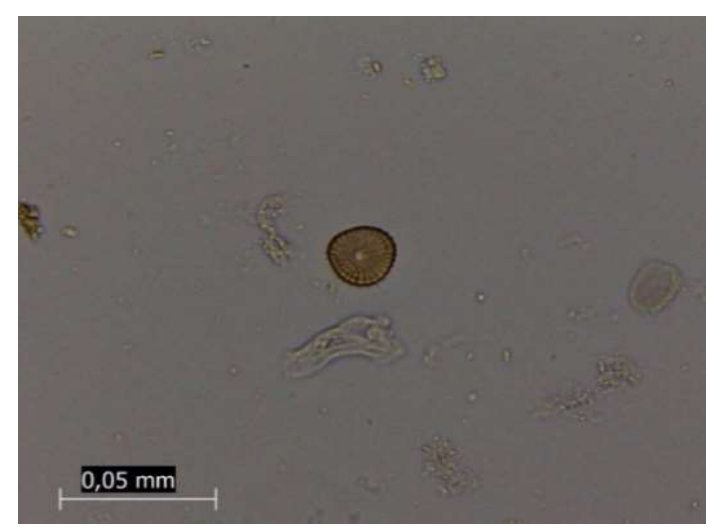

Gambar 3. Oospora yang ditemukan (perbesaran 400×)

Tabel 3. Perkembangan morfologi P. sorghi

\begin{tabular}{ccl}
\hline No & \multicolumn{1}{c}{ Fase } & \multicolumn{1}{c}{ Keterangan } \\
\hline 1 & Pertama (Pukul 00.00-01.00) & $\begin{array}{l}\text { Konidiofor mulai terbentuk. Bentuk konidiofor pada fase } \\
\text { pertama ini masih berbentuk seperti tombak yang tumpul } \\
\text { (Gambar 2a). }\end{array}$ \\
\hline 2 & Kedua (Pukul 01.00-02.00) & $\begin{array}{l}\text { Konidiofor sudah mulai terlihat membentuk percabangan, } \\
\text { dengan tingkat percabangan 1-2 (Gambar 2b). }\end{array}$ \\
\hline 3 & Ketiga (Pukul 02.00-03.00) & $\begin{array}{l}\text { Konidiofor sudah terlihat menunjukkan tingkat percabangan 1-3 } \\
\text { dan konidia sudah mulai akan terbentuk (Gambar 2c). }\end{array}$ \\
\hline 4 & Keempat (Pukul 03.00-04.00) & $\begin{array}{l}\text { P. sorghi sudah membentuk struktur yang sempurna, konidia } \\
\text { yang terlihat yaitu berbentuk oval (Gambar 2d). }\end{array}$ \\
\hline 5 & Kelima (Pukul 04.00-05.00) & $\begin{array}{l}\text { Konidia sudah masak, dan terdapat beberapa konidia yang mulai } \\
\text { terlepas dari konidiofor (Gambar 2e). }\end{array}$ \\
\hline 6 & Keenam (Pukul 05.00-06.00) & Konidia sudah terlepas dari konidiofor (Gambar 2f). \\
\hline
\end{tabular}

Perkembangan P. sorghi pada penelitian ini lebih lambat dibandingkan yang ditemukan oleh Budiarti et al. (2001) yang menyatakan bahwa konidia mulai terbentuk pada pukul 01.00-02.00 WIB, dan mulai masak pada pukul $02.00-03.00 \mathrm{WIB}$ pada suhu $24^{\circ} \mathrm{C}$, sedangkan pada penelitian ini konidiofor mulai terlihat pada pukul 00.00 WIB, kemudian pada pukul 01.0002.00konidiofor mulai membentuk tingkat percabangan. Konidia pada penelitian ini rata-rata muncul pada pukul 02.00-04.00 WIB, dan mulai masak rata-rata pada pukul 04.00-05.00 WIB pada suhu $17^{\circ} \mathrm{C}$.

Oospora $\boldsymbol{P}$. sorghi, oospora memiliki warna kuning terang hingga kecoklatan dengan bentuk bulat
(Gambar 3). Bentuk oospora yang diamati dibawah mikroskop majemuk kamera dengan perbesaran $100 " 400 \times$ yaitu bulat dengan warna kuning hingga kecoklatan sesuai dengan deskripi oleh CIMMYT (2012). Hal ini juga didukung penelitian yang dilakukan Setyowati (2018), yang menunjukkan bahwa P. sorghi memiliki oospora dengan bentuk bulat berwarna coklat.

\section{KESIMPULAN}

Berdasarkan hasil penelitian dapat disimpulkan bahwa patogen penyakit bulai yang ditemukan pada tanaman jagung di kabupaten Lampung Timur yaitu P. sorghi. Karakteristik dari P. sorghi mulai terlihat dengan 
adanya pembentukan konidiofor pada pukul 00.00 WIB, kemudian pada pukul 01.00 WIB konidiofor sudah mulai membentuk percabangan, pada pukul 02.00 WIB konidiofor sudh membentuk tingkat percabangan sempurna dan mulai terlihat bakal konidia, pada pukul 03.00 WIB P. sorghi sudah membentuk struktur yang sempurna, pukul 04.00 WIB konidia sudah mulai masak, dan pada pukul 05.00 WIB konidia mulai terlepas dari konidiofor, karakteristik lain dari $P$. sorghi adalah terdapat pembentukan oospora.

\section{DAFTAR PUSTAKA}

Badan Pusat Statistik (BPS) Provinsi Lampung. 2016. Produksi Tanaman Jagung di Provinsi Lampung. https://lampung.bps.go.id/. Diakses pada 16 Juni 2017 Pukul20.00 WIB.

Budiarti, S., Sutoro, Hadiatmi, dan Purwanti, H. 2001. Pembentukan dan evaluasi inbrida jagung tahan penyakit bulai. Prosiding Seminar Hasil Penelitian Rintisan dan Bioteknologi Tanaman. Bogor 26-27 Desember. Jawa Barat. Balai Penelitian Bioteknologi dan Sumberdaya Genetik Pertanian.

CIMMYT. 2012. Maize Doctor. http:// maizedoctor.org/downy-mildew-extendedinformation. Diakses pada 10 Agustus 2017 Pukul 20.00 WIB.
Hikmawati, Kuswinanti, T., Melina dan Pabendon, M.B. 2011. Karakterisasi morfologi Peronosclerospora spp., penyebab penyakit bulai pada tanaman jagung dari beberapa daerah di Indonesia. J. Fitomedika. 7 (3): 159-161.

Matruti, A.E., Kalay A.M, dan Uruilal, C. 2013. Serangan Peronosclerospora spp pada tanaman jagung di desa rumahtiga, kecamatan teluk ambon baguala kota ambon. $J$. Agrologia. 2(2): 109-115.

Mauke, S., Bahua M.I., dan Nurmi. 2015. Pertumbuhan dan produksi jagung manis (Zea mays sacaratha L.) melalui pemberian pupuk urea dan phonska. Jurnal Agroteknotropika. 4(1): 1-7.

Rustiani, U.S., Sinaga, M., Hidayat, S.H., dan Wiyono, S. 2015. Tiga spesies peronosclerospora penyebab penyakit bulai jagung di indonesia. Jurnal Berita Biologi. 14(1): 29-37.

Setyowati, E. 2018. Identifikasi dan Keragaman Peronosclerospora spp. Penyebab Penyakit Bulai pada Tanaman Jagung (Zea mays. L) di Kabupaten Pesawaran, Pringsewu, Tulang Bawang Barat, dan Bandar Lampung. Skripsi. Universitas Lampung. Lampung.

Sugiono. 2016. Gejala Penyakit Bulai Pada Tanaman Jagung. http://nad.litbang.pertanian. go.id. Diakses pada 16 Juni 2017 Pukul 21.00 WIB. 